ppi $201502 Z U 4645$

Esta publicación científica en formato digital es continuidad de la revista impresa ISSN-Versión Impresa 0798-1406 / ISSN-Versión on line 2542-3185Depósito legal pp $197402 Z$ U34

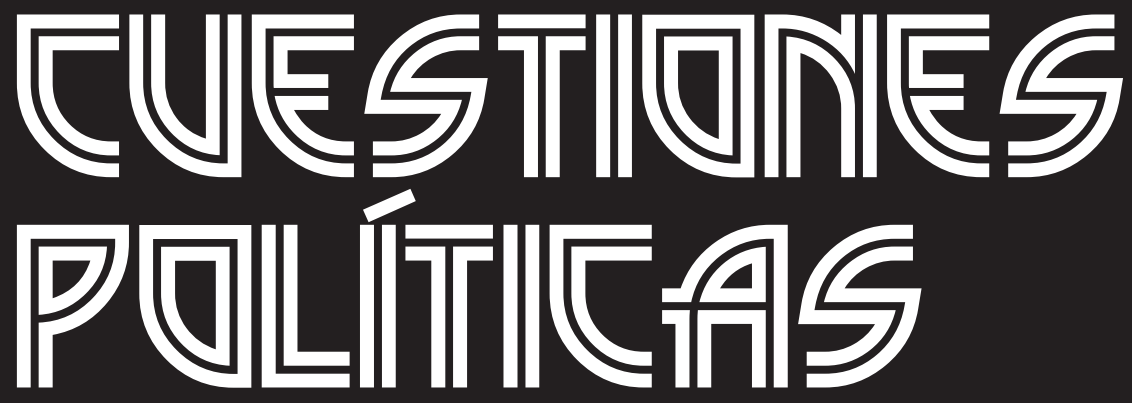

Instituto de Estudios Políticos y Derecho Público "Dr. Humberto J. La Roche" de la Facultad de Ciencias Jurídicas y Políticas de la Universidad del Zulia Maracaibo, Venezuela
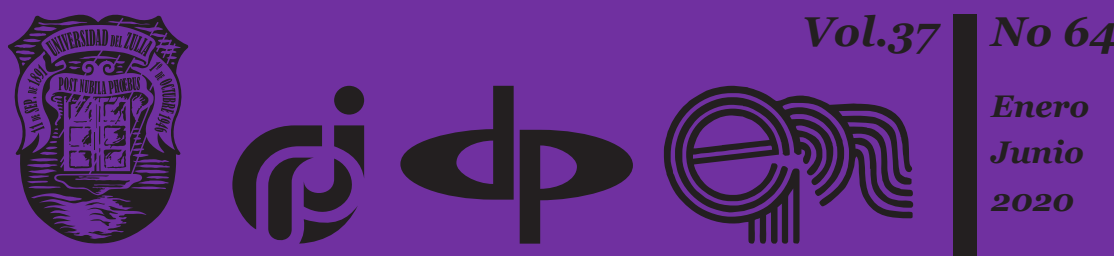


\title{
Constitutional Principles Of Judiciary: Peculiarities Of Formalization In The Cis Countries
}

\author{
Aleksej P. Treskov * \\ Lyudmila V. But'ko ** \\ Ruslan M. Dzidzoev *** \\ Alevtina E. Novikova**** \\ Andrey A. Solovyev *****
}

\begin{abstract}
The modern principles of judiciary, being an integrative constitutional-theoretical category, are the object of scientific research from the point of view of a meaningful interpretation, as well as the specific nature of formalization, including its the comparative legal aspect. In this regard, the research subject of this article is represented by the norms of the constitutions of the member states of the Commonwealth of Independent States. The article presents the analysis results, which allowed us identifying the nonstandard approaches to consolidate the constitutional principles of the judiciary in the focus group of acts. We associate these approaches with the compositional specific nature of principle reflection, as well as with the variably-substantive aspect, which quantitatively and qualitatively supplements the standard list of required fundamental ideas.
\end{abstract}

Keywords: constitutional principle; judicial principle; power of attorney; impartiality; Presumption of innocence.

\footnotetext{
* Rostov state University of railway engineering, 2 square of the Rostov Shooting Regiment of the National Militia, Rostov-on-don, 344038, Russia. Email: altreskov@yandex.ru.

** Northern Caucasian branch of the «Russian state University of justice», 187/1 Levanevskogo Street, Krasnodar, 350002, Russia. Email: Lvbutko@mail.ru

*** Kuban state University, 149the Stavropol Street, Krasnodar,350040.Email:kafedrakonstitutsionnogo@ mail.ru

****Belgorod State University, 85 Pobedy Street, Belgorod, the Belgorod region, 308015, Russia. Emai: novikova_a@bsu.edu.ru

***** Kutafin Moscow State Law University, 9, Sadovaya-Kudrinskaya Street, Moscow, 125993, Russia. Email: aa.solovev@mpgu.su
} 


\section{Principios constitucionales de la judicatura: peculiaridades de la formalización en los países de la Comunidad de Estados Independeintes}

\section{Resumen}

Los principios modernos de la judicatura, al ser una categoría teóricoconstitucional integradora, son objeto de investigación científica desde el punto de vista de una interpretación significativa, así como la naturaleza específica de la formalización, incluido su aspecto jurídico comparativo. En este sentido, el tema de investigación de este artículo está representado por las normas de las constituciones de los estados miembros de la Comunidad de Estados Independientes. El artículo presenta los resultados del análisis, lo que nos permitió identificar los enfoques no estándar para consolidar los principios constitucionales del poder judicial en el grupo focal de actores. Asociamos estos enfoques con la naturaleza específica de la composición de la reflexión principal, así como con el aspecto sustantivo variable, que complementa cuantitativa y cualitativamente la lista estándar de ideas fundamentales requeridas para el desarrollo de esta investigación.

Palabras clave: principio constitucional; principio judicial; poder judicial; imparcialidad; principio de presunción de inocencia.

\section{Introduction}

Within the framework of this work, the research attention is devoted to identifying specific (non-standard) approaches of constitutional formalization of the judiciary principles in the CIS countries (except for the Russian practice). We associate such approaches with the discovery of original formulations of the constitutional judiciary principles, which are found in a single option or have only one repetition. Previously, the author has compiled a catalog of constitutional standard principles for the similar group of states (Gribnau, 2002; Pineschi, 2015). At the same time, we consider the judiciary principles as a set of fundamental principles that determine its institutional and procedural aspects (Treskov et al, 2019; Treskov, 2018). With this approach, the fundamental provisions of the judicial system, legal proceedings and judiciary are laid in their content. 


\section{Methodology}

The study was based on a dialectic approach to the disclosure of legal phenomena and processes using general scientific (system, logical, analysis and synthesis) and particular scientific methods. The latter include formallegal, linguistic-legal, comparative-legal ones, which were used together to identify the judiciary principles. The focus group was made up of the CIS countries. The texts of their constitutions were taken from the database of the Internet library "Constitutions of the states (countries) of the world" (http://worldconstitutions.ru/)

\section{Discussion and Results}

Thus, we should indicate the compositional specific nature associated with the formalization of the judiciary principles in various parts of the constitution. As a rule, the judiciary principles are concentrated in special chapters/sections of the constitutions of the CIS countries (Chapter VII "Judiciary" in the Constitution of Azerbaijan, Chapter 7 "Courts and the Supreme Judicial Council" in the Constitution of Armenia, Chapter 6 "Court" in the Constitution of Belarus, Section VII "Courts and Judiciary" in the Constitution of Kazakhstan, Section VI "Judiciary" in the Constitution of Kyrgyzstan, Chapter IX "Judiciary" in the Constitution of Moldova, Chapter 8 "Court" in the Constitution of Tajikistan, Section VI "Judiciary" in the Constitution of Turkmenistan, Chapter XXII "Judiciary of the Republic of Uzbekistan" in the Constitution of Uzbekistan). However, the constitutions of Belarus and Moldova, characterized by a standard approach in combination with other constituent acts, nevertheless, have a specific nature in their compositional aspect. In Belarus, this resulted in the placement of a special Chapter 6 "Court" in Section IV "The President, Parliament, Government, and Court”.

The compositional feature of the Constitution of Moldova is that Chapter IX "Judiciary" of the Constitution of Moldova is divided into some parts. There is Part 1 dedicated to the courts. Further, there is Section $\mathrm{V}$ "Constitutional Court" outside the specified parts. Thus, the basic law divided the courts and the Constitutional Court. Perhaps the provisions of Article 134 of the mentioned Constitution explain this approach by the fact that the Constitutional Court is the only body of constitutional jurisdiction in the Republic of Moldova (Part 1), as well as independent of any other public authority with subordination only to the Constitution (Part 2). Let us note that the given Moldavian provisions are comparable with the constitutional decrees of Armenia by analogy of their approaches. Its 
special chapter lists the types of judicial bodies (Article 167 "Constitutional Court", Article 171 "Court of Cassation", Article 172 "Court of Appeal”, etc.) and the wording "when administering judiciary, the Constitutional Court is independent and subordinate only to the Constitution" only with reference to the Constitutional Court (Part 2 of Article 167).

Another compositional feature is present in the Constitution of Azerbaijan in connection with the formalization in its Chapter VIII of the basic rules on the Nakhchivan Autonomous Republic, which is part of Azerbaijan on the basis of the rights of self-governing territory. Thus, Part I of Article 135 of the Constitution of Azerbaijan legalized the power separation rules in the Nakhchivan Autonomous Republic, indicating that the judiciary is exercised by its courts, which are independent in resolving issues within their powers stipulated by the Constitution and laws of the Republic of Azerbaijan (Part II of Article 135).

Taking into account previous Russian constitutional experience of formalizing the regulations on the prosecutor's office (Article 129) in the chapter devoted to judiciary, we note that such approaches also exist in the constituent acts under consideration at the present time. For example, Article 83 on the prosecutor's office is placed in Section VII "Courts and Justice" of the Constitution of Kazakhstan. This also applies to the Constitution of Moldova. Part 3 "Prosecutor's Office" is individually specified in Chapter "Judiciary". Despite its separation in an independent part, it is nevertheless contained in a special chapter on judiciary, which states that justice is carried out in the name of the law only by the courts (Article 114).

It is interesting that the Constitution of Azerbaijan includes a wording according to which the Prosecutor's Office of the Republic of Azerbaijan and the defense participate in the administration of justice, except for the constitutional legal proceedings (Part IV of Article 125). In our opinion, the controversy of the given norm is nevertheless softened by the verb "participate".

The judiciary principles are dispersed in various norms in almost all the constitutions examined. In this regard, Article 127 of the Constitution of Azerbaijan, which consolidated the principles and conditions for the administration of justice, albeit in an inexhaustible manner, has become an exception.

Despite the fact that the Constitution of Armenia contains an independent chapter on judiciary, the fundamental provisions on it are collected in Article 63 devoted to the right to a fair trial and located in Chapter 7 "Courts and the Supreme Judicial Council". (Warner, S. B. 1936). This article includes such principles as fairness and publicity of the trial, independence and impartiality of the court, as well as reasonableness 
of trial duration. It should be emphasized that these principles are more specific for the formalization by the constitutions of the CIS countries.

If we talk about the unity of principles in one norm, the experience of the Constitution of Kazakhstan is interesting. Its Part 3 of Article 77 contains a finding that a judge should be guided by a number of principles in applying the law.

Then Part 4 of Article 77 of the Constitution of Kazakhstan names the above principles as "Principles of justice established by the Constitution", which are common and uniform for all the courts and judges of the Republic. In our opinion, ten formalized principles are fundamental ideas for justice, of course. However, the Constitution of Kazakhstan also reflects other principles related to both the institutional and procedural aspects of the judiciary. In this regard, the issues of naming the principles remaining outside Part 3 of Article 77 of the Constitution of Kazakhstan, but related to justice, is plenty logical.

It should be noted that the institutional aspect of the principle of justice administration only by the court stipulates the listing of specific types of courts in the constitutions (for example, Article 115 of the Constitution of Moldova, Article 84 of the Constitution of Tajikistan, Article 100 of the Constitution of Turkmenistan, etc.). In this regard, we found some specificity in the Constitution of Kyrgyzstan, since it provides for the establishment of arbitration courts for out-of-court settlement of disputes arising from the civil legal relations (Article 58), as well as aksakal courts (Article 59) in addition to the standard types of courts (Part 3 of Article 93).

Then let us indicate the constitutional principles of judiciary, each of which occurs in no more than two constituent acts of the focus group in question.

Thus, only Article 62 of the Constitution of Azerbaijan formalizes the principle of preventing changes in judicial jurisdiction. It is enshrined in article with the same name and means that everyone has the right to consideration of his/her case in a court established by law. Moreover, it is not allowed considering a person's case in another court without his/her consent.

Article 109 of the Constitution of Belarus legalized the principles that are absent in other constitutions under consideration. These are the principles of territoriality and specialization on which the court system is built.

The inadmissibility of absentee proceedings in the criminal cases, except for the cases stipulated by law, was found in Part VI of Article 127 of the Constitution of Azerbaijan, as well as in Part 2 of Article 99 of the Constitution of Kyrgyzstan. 
The principle of citizen participation in the administration of justice is contained in Part 1 of Article 93 of the Constitution of Kyrgyzstan in the following form "in the cases and within the procedure prescribed by law, the citizens of the Kyrgyz Republic have the right to participate in the administration of justice".

Article 75 of the Constitution of Kazakhstan reflects this principle in a similar wording specifying the participation of citizens as jurors.

The publicity of proceedings held in all courts is determined by Part $\mathrm{V}$ of Article 127 of the Constitution of Azerbaijan. The name "Publicity of court proceedings" of Article 117 of the Constitution of Moldova points out to the fact that "the court hearings are held openly in all courts" and then specifies the cases for a closed trial (Moldova, C. R. 2004). Thus, this approach identifies publicity and openness. But the wording of the principle of openness is more inherent in the considered group of constitutions (Article 114 of the Constitution of Belarus, Article 88 of the Constitution of Tajikistan, Article 105 of the Constitution of Turkmenistan and Article 113 of the Constitution of Uzbekistan).

The principle of publicity, coupled with openness, as already mentioned, was found in Article 63 of the Constitution of Armenia and in the original wording of Part 1 of Article 99 of the Constitution of Kyrgyzstan. According to its rulings, the openness of proceedings in all courts is combined with the public announcement of a court decision.

It is interesting that the principle of independence of the administration of justice specified in Article 80 of the Constitution of Kazakhstan, as well as in Part 1 of Article 98 of the Constitution of Kyrgyzstan contextually follows from the fundamental norms on the state financing of courts. Thus, the financing of courts ... should ensure the possibility of full and independent administration of justice.

In terms of guaranteeing the principle of judiciary's independence, the President of the Republic uses Part IV of Article 8 of the Constitution of Azerbaijan.

The independence and impartiality of the court is exclusively referred to in Article 60 of the Constitution of Belarus.

The competence and impartiality of the court are specified in Article 19 of the Constitution of Tajikistan.

In our opinion, we can talk about the originality of securing the principles of openness and responsibility of judiciary to people and the exercise of their powers in the interests of people (it is presented in Article 3 of the Constitution of Kyrgyzstan without specifying some features for the judiciary, but specifies them universally for the state). We believe that this conclusion follows from the very wording of the article, which states that 
state power in the Kyrgyz Republic is based on the state power principles, and the judicial branch is one of its branches. According to this approach, the judiciary is based on the principles addressed to the entire state power (in this case - openness and responsibility).

The authenticity of this approach is characterized by Part IV of Article 127 of the Constitution of Azerbaijan, which determined the equality of everyove before the law and the court as the basis for the administration of justice. The independently and fully specified principle is formalized in Part I of Article 25 of the Constitution of Azerbaijan. All other constitutions examined do not specify the principle of equality before the law and the court as the basis of justice. But as an independent principle, it is reflected in all constituent acts of the CIS member states. Only Article 28 of the Constitution of Armenia formalized universal equality before the law, without a court order (Vasilyan, S. 1994).

The Azerbaijani approach mentioned in Part IV of Article 127 was extended to the principle of presumption of innocence as the basis of justice (Part IX of Article 127 of the Constitution of Azerbaijan). Moreover, Article 63 is devoted to the formalization of the independent principle of presumption of innocence, according to which no one can be considered guilty of an offense without a court sentence (Part 5). It should be noted that this kind of approach is absent in other constitutions, but does not exclude independent consolidation of the principle of presumption of innocence with some variations.

The wording of the principle of innocence is typical: "no one/accused of a crime shall be presumed innocent until proved guilty according to the procedure established by law - by a court decision that has entered into legal force (Article 66 of the Constitution of Armenia, Article 26 of the Constitution of Belarus, Part 1 of Article 26 of the Constitution of Kyrgyzstan).

In Article 20 of the Constitution of Tajikistan, the principle of presumption of innocence is fraught with different chronological period "until the court verdict comes into force".

Article 21 of the Constitution of Moldova and Article 26 of the Constitution of Uzbekistan are also very distinctive. The first article of the same name established that "any person accused of committing a crime should be presumed innocent until proved guilty by law through a public trial, in which he/she is provided with all necessary protection guarantees". As can be seen, the effective court verdict is excluded from the article as a correlate of innocence. Article 26 of the Constitution of Uzbekistan has the same structure (Akbarzadeh, S. 1996). 


\section{Conclusions}

Making a conclusion on this study, we should note that the formalization of the constitutional principles of judiciary in the CIS countries is characterized by the standard and non-standard approaches. The first is associated with the presence of typical types of declared principles, found in more than three constitutions of the focus group of states. We associate the non-standard approaches of reflecting the constitutional principles of judiciary with the compositional specificity of their reflection, as well as with the variably-substantial aspect, which quantitatively and qualitatively supplements the standard list of required fundamental ideas.

\section{Bibliographic References ${ }^{6}$}

AKBARZADEH, Shahram. 1996. "Nation-building in Uzbekistan" In: Central Asian Survey. Available online. In: https://doi. org/10.1080/02634939608400931. Date of consultation: 03/04/2019.

BEYER, Judith. 2015. "Constitutional faith law and hope in revolutionary Kyrgyzstan” In: Ethnos. Available online. In: https://www.tandfonline. com/doi/abs/10.1080/o0141844.2013.841270?scroll=top\&needAccess $=$ true\&journalCode=retn20. Date of consultation: 06/04/2019.

DAVE, B. 2007. "Kazakhstan. Nations in Transit" Available online. In: http://www. freedomhouse. hu/images/fdh_galleries/NIT2007/ntkazakhstan. pdf. Date of consultation: 14/06/2019.

KHABRIEVA, T. Y. 2018. Constitutional Modernization in the CIS Countries: NewTrends. Herald of the Russian Academy of Sciences. Available online. In: https://link.springer.com/article/10.1134/S1019331618010033. Date of consultation: 14/06/2019.

GRIBNAU, Halin. 2002. Legitimacy of the Judiciary. In: E. Hondius and C. Joustra (red.) Netherlands Reports to the Sixteenth International Congress of Comparative Law, Antwerpen [etc.]: Intersentia, pp. 25-45.

KOFLER, B. 2008. Azerbaijan. In European Ombudsman-Institutions. Springer. Vienna, Austria.

6 Although the regulations for authors of this journal require the full names of the authors to be added to this list of references, unfortunately in some cases the source of origin only considers the initial of the name. 
MOLDOVA, C. R. 2004. Constitution of the Republic of Moldova. Constitutional Court. Chisinau, Moldova.

PINESCHI, Leo. 2015. General Principles of Law - The Role of the Judiciary. Springer International Publishing Switzerland. Zurich, Switzerland.

SHAW, G. M. 1995. The Constitution of Belarus: A Good First Step Towards the Rule of Law. Touro Int'l L. Rev., Vol. 6, p. 125.

TRESKOV, A; ARISTOV, E; NOVIKOVA, A; SOLOVYEV, A; KHLEBNIKOV, A. 2019. "Standard constitutional catalog of principles of judicial authority in the CIS countries" In: Humanities \& Social Sciences Reviews, No.7, Vol. 3, pp. 521-526.

TRESKOV, Albina Pavel. 2018. “Judiciary principles: experience of standard constitutional legalization in the CIS countries" In: Socio-political sciences, No. 4, pp. 112-116. (In Russian).

LIBRARY OF CONSTITUTIONS ROMAN PASHKOV. 2020. Constitutions of the states of the world. Available online. In: https://worldconstitutions. $\mathrm{ru} /$. Date of consultation: 11/11/2019.

VASILYAN, S. 1994. Towards Constitutionalism for the Republic of Armenia. Constellations. Yerevan, Armenia.

WARNER, S. B. 1936. Role of Courts and Judicial Councils in Procedural Reform. U. Pa. L. Rev., 85, p. 441. 

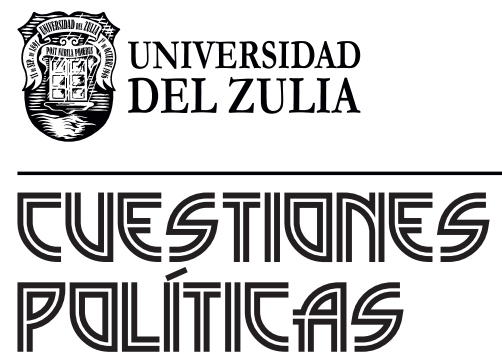

Vol. $37 \mathrm{~N}^{\circ} 64$

Esta revista fue editada en formato digital y publicada en junio de 2020, por el Fondo Editorial Serbiluz, Universidad del Zulia. Maracaibo-Venezuela 